\title{
Attaining Sustainable Rural Infrastructure through the National Rural Employment Guarantee Scheme in India
}

Commonwealth Journal of Local Governance

Issue 4: November 2009

http:/lepress.lib.uts.edu.au/ojs/index.php/cjlg

\section{Polly Datta}

Independent Researcher

Kolkata, India

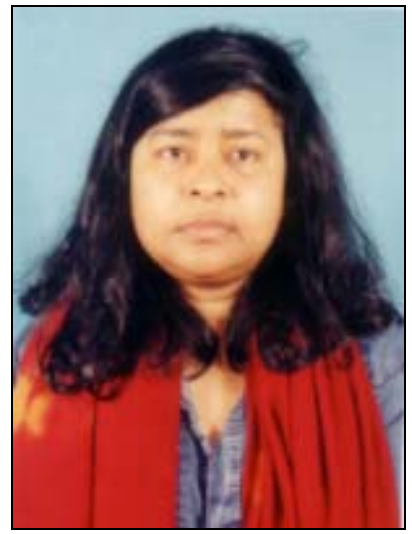

The enactment of the National Rural Employment Guarantee Act (NREGA) 2005, with its rights-based approach through a time-bound employment guarantee and legal framework, has marked a paradigm shift not only from other wage-employment programmes hitherto pursued in India, but also from neo-liberal reforms undertaken since 1991. The Act came into force on 2 February 2006 and was implemented in a phased manner. In Phase I it was introduced in 200 of the most backward districts of the country; Phase II added another 130 districts in 2007-08; and in Phase III the scheme was further extended to the remaining 274 rural districts of India from 1 April 2008.

The demand-driven approach of NREGA ensures that adult members of a rural household willing to do any public-related unskilled manual work at the statutory minimum wage are provided a legal guarantee for 100 days of employment for each financial year. If the State 
government fails to provide work within 15 days of application being made, the applicant is entitled to an unemployment allowance.

The National Rural Employment Guarantee Scheme (NREGS) requires that a Perspective Plan, concerned mainly with water conservation, minor irrigation, land development and rural connectivity, is to be prepared for whole districts to provide a Shelf of Possible Projects to be taken up under the scheme as and when demand for work arises. The Act is also a significant vehicle for strengthening decentralization and deepening the process of democracy by giving a pivotal role to the Panchayati Raj Inststitutions (PRIs) in planning (Panchayats at District, Intermediate and Village levels are the principal authorities for planning); monitoring (a regular social audit of all works within the jurisdiction of each Panchayat is expected to be carried out by the Gram Sabha ${ }^{1}$ ); and implementation.

\section{Low level of absorption of labour in rural India}

According to the $11^{\text {th }}$ Planning Commission's (2007-12) estimate $27.5 \%$ of the total population of India live below the poverty line, and about $73 \%$ of these poor live in rural areas and are primarily small and marginal farmers. A number of studies indicate that over the past few decades the capacity of the agricultural sector to absorb labour has gone down due to sharp decline in public investment in rural infrastructure such as irrigation. Consequently, there has been a steady decrease in the per capita output of agriculture, which necessitates a massive increase in public investment in rural India. The annual rate of growth of rural employment was around 0.5\% per annum between 1993-94 to 1999-2000 as compared to $1.7 \%$ per annum between 1983-84 and 1993-94. Also the current daily status unemployment rate in rural areas increased from $5.63 \%$ in $1993-94$ to $7.21 \%$ in $1999-00$ (Chakraborty 2007, p.5). However, as shown by the 2001 Census data provided by the National Sample Survey Organization (NSSO), the number of marginal workers grew significantly in the countryside in the 1990s when compared to the 1980s, hence the problem is not merely related to outright unemployment, but also under-employment. Rural labourers are forced to work for very low wages in the non-formal sector. The deceleration of rural employment growth was further reinforced by a sharp cutback in public spending on rural employment programmes. Direct expenditure on these programmes was $0.2 \%$ of GDP in

\footnotetext{
${ }^{1}$ A twice-yearly meeting of eligible voters (adults aged 18 years or more) in each Panchayat.
} 
1996-97, but only $0.13 \%$ of GDP in 2001. It increased to $0.40 \%$ in $2002-03$ but again declined to $0.33 \%$ in 2006-07 (Chakraborty 2007, p. 17). This situation demanded providing a safety net to rural communities in the form of guaranteed employment through a programme like NREGA. But as well as ensuring rural employment, productivity enhancement in rural communities is also necessary to generate secondary benefits and improve the rural economy's ability to absorb labour.

\section{Criticism of NREGA to date}

NREGA has thus far received two broad types of criticisms. Firstly, pro-market liberals tend to denigrate the Act itself on the grounds that NREGA will accelerate excessive fiscal deficits on the one hand, and encourage corruption on the other. Secondly, other groups including advocates of NREGA, feel that it will actually crowd out private investment, particularly in agriculture, and can only lay the foundations for non-inflationary growth in the medium term if it is accompanied by substantial upgrading of rural infrastructure. These groups feel that the government has so far been approaching the NREGA as purely a wageemployment programme thus negating the development potential of the Act. Furthermore, they argue that there should be no trade-off between expenditures on providing legal rights to rural employment and upgrading infrastructure, but rather that they are complementary.

Furthermore, the three pillars of the rights-based approach of NREGA (a legal guarantee of 100 days of rural employment, a statutory minimum wage, and ensuring unemployment allowances) seemed to be at stake when the 2007 report of the Comptroller of Auditor General (CAG) - the most extensive assessment of the implementation of the scheme so far - highlighted serious procedural lapses in its implementation. These included lack of adequate administrative and technical manpower in rural local governments that adversely affected the preparation of plans, scrutiny, approval, monitoring and measurement of work done, as well as lack of maintenance of the stipulated records at Gram Panchayat level. Absence of recorded dates of applications for work under NREGA, as CAG observed, made it difficult to establish entitlements to employment allowances and also to verify the provision of the work within the legal guarantee of 100 days. 


\section{Poor quality of works taken under NREGS}

Many studies indicate that giving preference to employment creation over the creation of durable productive assets under NREGS seems to have resulted in poor quality works, increasing numbers of incomplete projects and very low levels of maintenance. This is exacerbated by inadequate technical support for the scheme and poorly designed implementation strategies: “...the emphasis is more on spending a large amount of money than on ensuring quality in works execution” (Ambasta et al. 2008, p. 44). For example, treeplanting may be done under NREGS but no provision made for watering nor any protection planned against grazing (ibid., p. 44). Similarly, water-harvesting structures have been created under NREGS without any provision for catchment protection, and eventually most of these have silted up beyond repair (CSE 2008, p. 43).

Moreover, with a view to generating more workdays and creating labour-intensive projects, the Act bans the use of machines and the commissioning of contractors, who tend to do most work using labour-displacing machinery. The Act also requires a 60:40 ratio of wages to materials costs. Many observers feel that compliance with this strict norm for each project, along with the restriction on the use of machinery, has led to problems with respect to the generation of durable assets. The study undertaken by CSE (2008 p. 42) observed that about 80 percent of the assets created under the Act are not providing sustainable benefits.

Another problem is that there is no compulsion on implementing agencies under NREGA to actually complete a project. Thus local governments start labour intensive projects to meet demands for job creation but many of them are abandoned midway. Many feel that instead of opening up new projects, it is more important to complete existing works within a set timeframe. In 2006-07, 53.7\% of the total number of schemes under NREGA remained incomplete. Respective figures for the financial years 2007-08 and 2008-09 are 54.1\% and $56.1 \%$ as evidenced from the table below. 


\begin{tabular}{|l|l|l|l|}
\hline & $\begin{array}{l}\text { Financial Year } \\
\mathbf{2 0 0 6 - 0 7}\end{array}$ & $\begin{array}{l}\text { Financial Year } \\
\mathbf{2 0 0 7 - 0 8}\end{array}$ & $\begin{array}{l}\text { Financial Year } \\
\text { 2008-09* }\end{array}$ \\
\hline Number of Districts Involved & 200 & 330 & 615 \\
\hline $\begin{array}{l}\text { Employment Provided: } \\
\text { Person Days per Household }\end{array}$ & 43 days & 42 days & 47 days \\
\hline $\begin{array}{l}\text { Total Number of Works (In } \\
\text { Lakhs) }\end{array}$ & 835,000 & $1,788,000$ & $2,643,000$ \\
\hline \% Works Completed & $46.3 \%$ & $45.9 \%$ & $43.9 \%$ \\
\hline Type of Works & \multicolumn{3}{|l}{} \\
\hline Water Conservation & $54 \%$ & $49 \%$ & $45 \%$ \\
\hline Irrigation Facility & $10 \%)$ & $15 \%$ & $20 \%$ \\
\hline Rural Connectivity & $21 \%$ & $17 \%$ & $18 \%$ \\
\hline Land Development & $11 \%$ & $16 \%$ & $15 \%$ \\
\hline Other & $4 \%$ & $3 \%$ & $0.93 \%$ \\
\hline
\end{tabular}

*Provisional results to March 2009

Source: Guidelines on Convergence with National Rural Employment Guarantee Scheme, Ministry of Rural Development, Government of India, 2009, New Delhi (website: http://www.nrega.nic.in)

\section{Need and scope for convergence}

As noted above, interested parties have asked whether the success of the Act should only be measured in terms of work days provided to rural households, or whether more emphasis should be placed on creating productive and durable assets which would in turn ensure long term rural employment. They argue that the government should ensure better coordination between line departments and with other funding schemes with a view to complementing NREGS with additional mechanized work. For example, non-engineered brick soling roads created under NREGS could be metalled with engineering inputs by linking the scheme with Pradhan Mantri Gtram Sadak Yojna (PMGSY), the Prime Minister’s Rural Road Project.

The Ministry of Rural Development (MoRD) does in fact appear to have realized that NREGS with its inter-sectoral approach has the potential for convergence with other departments like the Ministry of Water Resources (MoWR), Ministry of Environment and Forests (MoE\&F), Department of Land Resources, Ministry of Agriculture (MoA), Ministry 
of Human Resources, and the Ministry of Women and Child Development. There is also scope to converge with schemes like PMGSY, the National Afforestation Programme (NAP), Accelerated Irrigation Benefits Programme (AIBP), Farmers Participation Action Research Programme (FPARP) and the Common Area Development and Water Management Programme (CAD\& WM). Such linkages could create a 'second generation' NREGS that effectively creates durable assets. Inter-sectoral convergence would also add value through resource and activity synergies as well as infusion of technological inputs and professional quality in planning and implementation (MoRD, 2009).

Given the current situation of a plethora of schemes with similar activities, there is a great need to rationalize their planning and implementation to avoid duplication and redundancy. A convergence model, as conceptualised by MoRD (2009) would draw together existing schemes and resources, rather than create a new scheme with additional resources, thus optimizing public investment and achieving shared objectives. For example, convergence between NREGA and ongoing programmes like PMGSY could be instrumental in achieving the goal of the Rural Development Plan: Vision 2025 (prepared by MoRD) to provide proper connectivity to all villages across the country.

Similarly, convergence between NREGA and the National Afforestation Programme (NAP) would be mutually beneficial. MoE\&F has set the target of one third of the country's land area under forest or tree plantations, as envisaged in the National Forest Policy, 1988. This cannot be accomplished by the MoE\&F alone due to the volume of manpower and other resources required for the task, some of which could be provided through NREGS.

Also, there are several programmes of MoWR being implemented across the country that involve works similar or complementary to NREGA projects. MoWR has identified a gap between the irrigation potential being created and that utilized because many irrigation projects have been operating below their potential due to inadequate maintenance. This has resulted in the problem of low efficiency of water usage and low productivity. Integration with NREGS could ensure better maintenance of projects implemented by MoWR. 


\section{How inter-sectoral convergence could function}

According to MoRD's proposals, NREGA works are expected to become a subset of all those other programmes which have a kuccha (earthworks) component and which require a large labour force, particularly semi-skilled and unskilled labour. For example, through convergence with the Accelerated Irrigation Benefits Programme (AIBP), earthworks such as embankment construction and minor irrigation schemes, along with other labour intensive work, could be carried out under NREGS, while works requiring machines can be executed under AIBP. The timing of kuccha works under convergence should be planned taking into account the agriculture lean season when participation in the NREGA workforce is high.

Convergence of works could be affected in several ways:

- Gap filling e.g. roadside planting along roads constructed under PMGSY.

- Dovetailing inputs into common projects identified through the NREGA Perspective Plan.

- Area-based complementary projects, e.g. NREGS could fund supplementary roadworks in an area to link villages that cannot be connected under the PMGSY, which allows for only limited rural connectivity.

- Value addition to NREGA works e.g. metalling roads built under NREGS through PMGSY

- Technical support for ensuring quality in planning, selection and execution of NREGS works e.g. the Ministry of Agriculture (MoA) can provide a database for the selection of appropriate works in a particular area at the planning stage along with quality enhancing technologies/technical support at the design and execution stages under NREGS.

The convergence model can thus provide a basis for sustainable development, as shown in the flow chart below. 


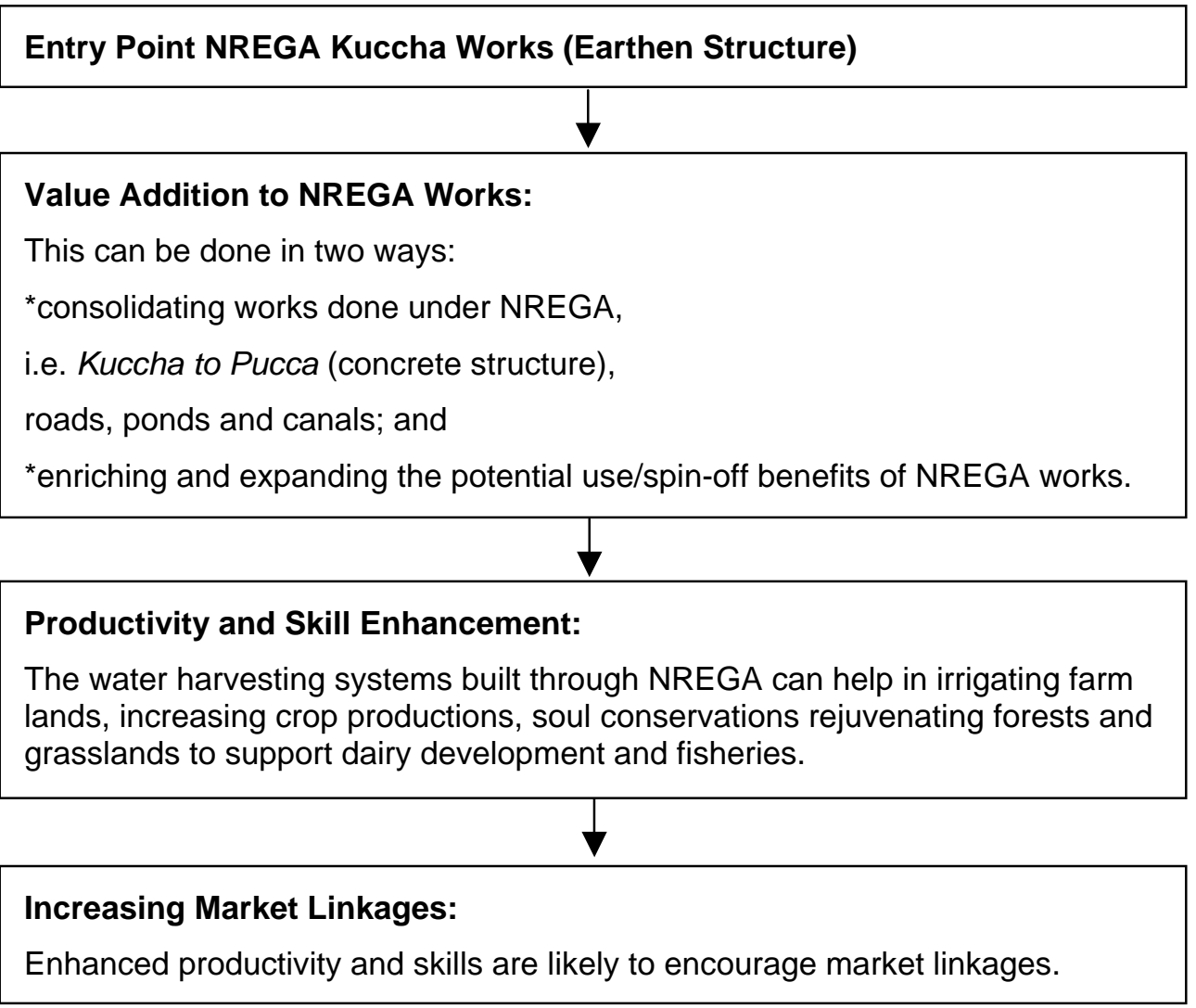

\section{Conclusion}

Over the past few decades the capacity of the agricultural sector to absorb rural labour has declined due in part to a sharp reduction in public investment in rural infrastructure. In this situation, NREGA was introduced with its right-based framework to offer an employment guarantee to the rural poor. However, some critics feel that to date the government has been approaching NREGA purely as a wage- employment programme, thus negating its development potential and giving preference to employment generation over the creation of durable productive assets generation. But these two objectives must be seen as complementary. Studies have shown that there is a quite distinct and positive relationship between rural infrastructure development and the reduction of rural poverty through increases in wages and household income, income per acre of field crop, and nonagricultural employment. According to an estimate made by the International Food Policy Research Institute (IFPRI) for each additional Rs.1 million invested in roads, 165 people would be lifted above the poverty line (IFPRI, 1999, p. 39). 
In this context, an inter-sectoral convergence model has been advanced by the Ministry of Rural Development. Successful pursuance of this convergence model is expected to create huge potential for upgrading, renovating and creating sustainable rural infrastructure on a massive scale that has not so far been undertaken in India. NREGA would thus be positioned not as an old style welfare programme, but rather a development initiative to create durable assets across a wide range of works. It remains to be seen to what extent this model of convergence between NREGS and other existing schemes of various line departments can deliver the expected boost to rural infrastructure.

\section{References:}

Ambasta, P, Vijay Shankar, P S and Shah, M 2008, 'Two Years of NREGA: The Road Ahead', Economic and Political Weekly, 23 February 2008, p. 44.

Centre for Science and Environment (CSE) 2008, NREGA, Opportunities and Challenges, Centre for Science and Environment, New Delhi.

Chakrabarty, P 2007, 'Implementation of the National Rural Employment Guarantee Act in India: Spatial Dimensions and Fiscal Implication', Working Paper No. 505, The Levy Economics Institute of Bard College, Annandale-on-Hudson, New York.

Comptroller of Auditor General (CAG) 2007, Performance Audit of Implementation of National Rural Employment Guarantee Act, 2005 (NREGA), Draft Report, Comptroller of Auditor General, New Delhi.

Department For International Development 2007, Status of NREGA Implementation: Grassroots Learning and Ways Forward, $1^{\text {st }}$ Monitoring Report, Poorest Area Civil Society (PACS) Programme, New Delhi, accessed on June, 15, 2009, <http://www.empowerpoor.org/downloads/Revised\%20Report\%20status\%20of\%20NREGA\% 20101007.pdf $>$.

Dreze, Jean 2007, 'NREGA: Dismantling the Contractor Raj', The Hindu, 20 November 2007, accessed 27 November 2009, $<$ http://www.thehindu.com/2007/11/20/stories/2007112056181000.htm>.

Dutt, Ruddar 2008, 'Dismal Experience of NREGA: Lessons for the Future’, Mainstream, Vol. XLVI, No.17, accessed 27 November 2009, <www.mainstreamweekly.net/article641.html>.

Fan, S, Hazell, P and Thorat, S K 1999, Linkages between Government Spending, Growth, Poverty in Rural India, Research Report 110, International Food Policy Research Institute (IFPRI), Washington DC.

Ministry of Rural Development (MoRD) 2009, Guidelines On Convergence With National Rural Employment Guarantee Scheme, Government of India, New Delhi.

Siddhartha and Vanaik, A 2008, 'CAG Report on NREGA: Fact and Fiction', Economic and Political Weekly, June 21-27 2008, vol. XLIII, no 25, p. 39-45.

Sridhar, V 2005, 'Empowering the Rural Poor', Frontline, Vol.22, Issue 19, accessed 27 November 2009, <http://www.hinduonnet.com/fline/fl2219/stories/20050923005402200.htm>. 
Tiwari, R and Pandey, G 2008, 'It’s Official: In Poorest States, Job Funds Don’t Reach the Poor', Indian Express, 7 January 2007, accessed 27 November 2009,

<http://www.indianexpress.com/news/its-official-in-poorest-states-job-funds/258873/>.

United Nations Development Programme (UNDP) 2006, Support to Operationalization of the

National Rural Employment Guarantee Act, United Nations Development Programme, New Delhi. 